\title{
ANALISIS KORELASI SEKTOR PERTANIAN DENGAN KEMISKINAN DI PROVINSI SUMATERA UTARA
}

\section{CORRELATION ANALYSIS OF AGRICULTURE SECTOR AND POVERTY IN NORTH SUMATERA PROVINCE}

\author{
Siti Sabrina Salqaura*1 \\ ${ }^{1}$ Fakultas Pertanian,Universitas Medan Area. \\ ^Email Corresponding: sitisabrina@staff.uma.ac.id
}

\begin{abstract}
ABSTRAK
Sektor pertanian merupakan sektor utama diberbagai negara sebelum adanya perkembangan teknologi yang kemudian sektor pertanian menggerakkan sektor industri dan jasa. Penelitian ini bertujuan untuk menganalisis hubungan sektor pertanian dengan kemiskinan di Provinsi Sumatera Utara menggunakan analisis korelasi sederhana. Data yang digunakan merupakan data panel yaitu gabungan data crosssection kabupaten dan kota sejumlah 33 di Provinsi Sumatera Utara dengan time series dari tahun 2011 hingga 2019. Metode yang digunakan adalah metode deskriptif dan analisis korelasi. Hasil analisis menunjukkan bahwa sektor pertanian dan kemiskinan cukup kuat dengan nilai positif sebesaar 0,4499. Perlunya peningkatan pendidikan petani, jaminan petani dan kemandirian petani agar sektor pertanian yang merupakan sektor utama untuk daerah perdesaan menjadi sektor yang dapat mengeluarakan masyarakat dari kemiskinan dan diperlukan penelitian dengan metode yang lain untuk memperkuat argument dari peneliti..
\end{abstract}

Kata kunci: Kemiskinan, Korelasi, PDRB Pertanian

\begin{abstract}
The agricultural sector was the main sector in various countries before the development of technology, which then drove the industrial and service sectors. This study aims to analyze the relationship between the agricultural sector and poverty in North Sumatra Province using simple correlation analysis. The data used is panel data which are a combination of cross-sectional data of 33 districts and cities in North Sumatra Province with time series from 2011 to 2019. The method used is descriptive method and correlation analysis. The results of the analysis show that the agricultural sector and poverty are quite strong with a positive value of 0.4499 . It is necessary to improve farmer education, farmer guarantee and farmer independence so that the agricultural sector, which is the main sector for rural areas, becomes a sector that can bring people out of poverty and research with other methods is needed to strengthen the arguments of the researchers.
\end{abstract}

Keywords: Poverty, Correlation, PDB Agriculture

\section{PENDAHULUAN}

Kemiskinan merupakan musuh dari setiap negara dan pengentasan kemiskinan merupakan salah satu tujuan pembangunan nasional yang terkandung dalam Pembukaan Undang-Undang Dasar 1945. Pembangunan diharapkan
akan
meningkatkan
pertumbuhan
ekonomi dan mampu mengurangi pengangguran, meningkatkan kesejahteraan umum atau menuntaskan kemiskinan. Kemiskinan merupakan salah satu indikator tidak tercapainya 


\section{ANALISIS KORELASI SEKTOR PERTANIAN DENGAN KEMISKINAN \\ DI PROVINSI SUMATERA UTARA}

Siti Sabrina Salqaura

kesejahteraan masyarakat dalam suatu negara maupun wilayah.

Provinsi memiliki wewenang (desentralisasi) tertentu untuk membuat keputusan mengenai sektor yang akan di eksplorasi maupun terkait dengan modal yang ditanamkan dalam suatu wilayah dengan landasan untuk meningkatkan kesejahteraan masyarakat yang sesuai dengan kekayaan wilayah atau provinsi tersebut. Provinsi Sumatera Utara merupakan provinsi yang luas sebesar $72.981 \quad \mathrm{~km} 2$ terdiri dari 33 kabupaten/kota. Perekonomian digerakkan oleh berbagai sektor ekonomi, sekarang ini urutan sektor ekonomi sudah menjadi sektor jasa, industri dan terakhir merupakan sektor pertanian berdasarkan kontribusinya terhadap PDRB.

Sebagai negara pengekspor kelapa sawit terbesar di dunia dengan jumlah ekspor 27.841 .972 ton rata-rata per tahun dan nilai ekspor 18.046.110 ribu US\$ rata-rata per tahun, kelapa sawit telah menjadi komoditas unggulan bagi Indonesia. Dengan besarnya peran sektor perkebunan kelapa sawit tidak hanya bagi nasional namun juga global, tenaga kerja atau petani perkebunan kelapa sawit seharusnya mendapatkan kehidupan yang layak dan sejahtera hal ini kaitannya dengan penelitian Pratama (2014) yang menyatakan bahwa peningkatan pendapatan berpengaruh negative terhadap kemiskinan. Hampir 70 persen perkebunan kelapa sawit di Indonesia terletak di Sumatera. Sebagai daerah dengan total luas lahan terbesar di Indonesia, Sumatera menjadi sentra produksi kelapa sawit dan memberikan kontribusi ekonomi yang besar untuk PDRB masing-masing daerah yang berada di Sumatera, termasuk Provinsi Sumatera Utara yang merupakan penghasil kelapa sawit terbesar ketiga di Indonesia setelah Provinsi Riau dan Kalimantan Tengah. Perkebunan merupakan salah satu subsektor yang ada di sektor pertanian.

Sektor pertanian Provinsi Sumatera Utara yang paling menonjol adalah sektor perkebunannya. Namun secara keseluruhan Provinsi Sumatera Utara memiliki berbagai keragaman jenis tanaman yang ada. Zuhdiyaty \& Kaluge (2017) menunjukkan hasil penelitian bahwa terdapat pengaruh antara IPM dengan kemiskinan sedangkan pertumbuhan ekonomi dan Tingkat Pengangguran Terbuka tidak mempengaruhi kemiskinan. Niara \& Zulfa (2019) menemukan bahwa sektor pertanian tidak memiliki pengaruh terhadap kemiskinan dan memiliki koefisien negative. Variabel konsumsi dan IPM merupakan variabel yang signifikan negative terhadap kemiskinan menurut Pratama (2014). Sihombing \& Bangun (2019) melakukan analisis korelasi sektor pertnaian terhadap tingkat 
kemiskinan di sumatera utara menunjukkan bahwa terdapat hubungan signifikan yang bersifat negative antara sektor pertanian dengan kemiskinan. Purnami dan Saskara (2016) menemukan bahwa kontribusi sektor pertanian berpengaruh signifikan positif pada kemiskinan. Sektor pertanian masih merupakan sektor yang menyerap tenaga kerja dalam jumlah yang banyak dan hal ini diharapkan dapat meningkatkan pertumbuhan. Penelitian ini bertujuan untuk mengetahui pengaruh sektor pertanian terhadap kemiskinan di Provinsi Sumatera Utara dengan menggunakan panel data dari tahun 2011 hingga 2019.

\section{METODE PENELITIAN}

Penelitian ini menggunakan data dari tahun 2011 hingga 2019. Lokasi penelitian dipilih secara purposive sampling karena Provinsi Sumatera Utara merupakan salah satu Provinsi dengan sektor pertanian yang beragam dan sektor perkebunannya yaitu salah satunya perkebunan kelapa sawit merupakan salah satu yang terluas di Indonesia. Penelitian ini menggunakan data kabupaten dan kota di Provinsi Sumatera Utara yang terdiri dari Kabupaten Nias, Mandailing Natal, Tapanuli Selatan, Tapanuli Tengah, Tapanuli Utara, Toba Samosir, Labuhanbatu, Asahan Simalungun, Dairi, Karo, Deli Serdang, Langkat, Nias
Selatan, Humbang Hasundutan, Pakpak Bharat, Samosir, Serdang Berdagai, Batu Bara, Padang Lawas Utara, Padang Lawas, Labuhanbatu Selatan, Labuhanbatu Utara, Nias Utara, Nias Barat, serta Kota Sibolga, Tanjungbalai, Pematangsiantar, Tebing Tinggi, Medan, Binjai, Padangsidimpuan dan Gunungsitoli. Penelitian ini menggunakan software Eviews10. Data dikumpulkan dari berbagai publikasi Badan Pusat Statistik Provinsi Sumatera Utara dalam Angka dengan variasi berbagai tahun.

Variabel yang digunakan adalah PDRB Sektor Pertanian dengan harga konstan tahun 2010 dan data jumlah masyarakat miskin. Analisis korelasi PDRB sektor pertanian dan kemiskinan di Provinsi Sumatera Utara menggunakan analisis korelasi sederhana untuk mengetahui hubungan linier antara variabel tersebut. Nilai atau indikator korelasi yang mendeskripsikan hubungan antar variabel dapat dilihat dengan koefisien korelasi, yang merupakan suatu ukuran arah dan kekuatan hubungan linier antara dua variabel random (Watson \& Craft dalam Sunyoto, 2007 : 31). Penelitian ini menggunakan aplikasi Eviews, sehingga untuk mencari korelasi antara variabel $\mathrm{X}$ dan $\mathrm{y}$ dapat dihitung dengan mencari sums-of squared crossproducts dengan rumus :

$$
\operatorname{SsCP}(\mathrm{X}, \mathrm{Y})=\sum_{i}\left(X_{i}-\hat{\mu}_{X}\right)\left(Y_{i}-\hat{\mu}_{Y}\right)
$$

$\hat{\mu}_{X}$ dan $\hat{\mu}_{Y}$ merupakan rerata. 


\section{ANALISIS KORELASI SEKTOR PERTANIAN DENGAN KEMISKINAN \\ DI PROVINSI SUMATERA UTARA}

Siti Sabrina Salqaura

Kemudian covarian dihitung dengan membagikan SSCP dengan jumlah observasi dengan atau tanpa koreksi derajat bebas :

$$
\hat{\sigma}(X, Y)=\frac{\sum_{i}\left(X_{i}-\hat{\mu}_{X}\right)\left(Y_{i}-\hat{\mu}_{Y}\right)}{n-k}
$$

Dimana $\mathrm{n}$ merupakan jumlah observasi pada variable $X$, berpasangan dengan $Y$ dan $\mathrm{k}$ adalah derajat kebebasan. Sehingga rumus korelasi menjadi :

$$
\hat{\rho}(X, Y)=\frac{\hat{\sigma}(X, Y)}{\widehat{(\sigma}(X, X) \cdot \hat{\sigma}(Y, Y))^{1 / 2}}
$$

Rumus tersebut untuk ordinary atau korelasi Pearson product moment yang tercantum dalam panduan online Eviews. Koefisien korelasi dapat memiliki nilai positif dan negative dengan nilai berkisar dari -1 hingga 1 . Korelasi negative ditunjukkan dengan koefisien korelasi negative begitu juga sebaliknya. Interpretasi koefisien korelasi sebagai berikut (Anindita,2017) :

Tabel 1. Interpretasi Koefisien Korelasi

\begin{tabular}{cc}
\hline Koefisien Korelasi (positif atau negative) & Interpretasi \\
\hline $0,80-1$ & Sangat Kuat \\
$0,60-0,799$ & Kuat \\
$0,40-0,599$ & Cukup Kuat \\
$0,20-0,399$ & Rendah \\
$0,00-1,99$ & Sangat Rendah \\
\hline
\end{tabular}

Sumber : Anindita, 2017

\section{HASIL DAN PEMBAHASAN}

Sektor pertanian merupakan sektor yang dasar bagi suatu negara ketika negara tersebut belum berkembang dan memiliki sektor industri dan jasa. Dari sektor pertanian kemudian meluas menjadi sektor industri yang menggunakan olahan sektor pertanian sebagai bahan dasarnya kemudian meluas menjadi sektor jasa dengan transportasi untuk mendistribusikan sektor pertanian. Dengan kemajuan teknologi manusia yang terus berkembang dan kebutuhan manusia juga terus berkembang sehingga negara negara maju sektor utamanya yang awalnya dari sektor pertanian kemudian fokus sektornya akan bergeser ke sektor industri dan kemudian bergeser ke sektor jasa.

Pertanian tidak hanya memperluas sektor perekonomian namun juga menjadi bahan dasar untuk industri, kemudian yang paling penting adalah sektor pertanian merupakan sektor yang menyerap tenaga kerja dalam jumlah yang paling banyak meskipun terus berkurang terutama di pedesaan. Meskipun begitu menurut Provinsi Sumatera Utara dalam angka tahun 2019 sektor pertanian merupakan sektor kedua terbesar yag menyerap tenaga kerja terbesar setelah industri yaitu dengan industri menyerap sebesar 47,77 persen 
sedangkan sektor pertanian menyerap sebesar 35,53 persen.

Provinsi Sumatera Utara terdiri dari berbagai sub-sub sektor pertanian yang mencakup tanaman pangan yang luas panen dan produksi mengalami peningkatan seperti padi sawah dan padi ladang. Selain itu tanaman palawija juga cukup potensial. Jagung, ubi jalar, ubi kayu, kacang tanah mengalami penginkatan dari tahun 2018 ke tahun 2019, sedangkan tanaman kedelai dan kacang hijau menurun produksinya. Tanaman hortikultura utama di Provinsi Suamtera utara ada 26 jenis yaitu tanaman sayuran, bawang daun,bawang merah,bawang putih, cabai besar, cabai rawit dan lain sebagainya. Salah satu pusat perkebunan di Indonesia adalah di
Provinsi Suamtera Utara. Komoditas hasil perkebunan yang utama adalah kelapa sawit, karet, kopi, coklat dan tembakau. Pada sub-sektor kehutanan produksi hasil huta di Sumatera Utara dikelompokkan menurut jenisnya yaitu kayu bulat dan kayu olahan. Peternakan dengan populasi yang besar terdiri dari kuda, sapi potong, kerbau dan sapi perah sedangkan jumlah populasi ternak kecil terdiri dari kambing, domba dan babi. Untuk suk sektor perikanan sebanyak 158.667 orang nelayan yang bekerja penuh pada tahun 2018. Dengan keragaman tersebut dan Provinsi Sumatera Utara yang besar dan terdiri dari 33 kabupaten dan kota pertanian memiliki pengaruh yang cukup besar.

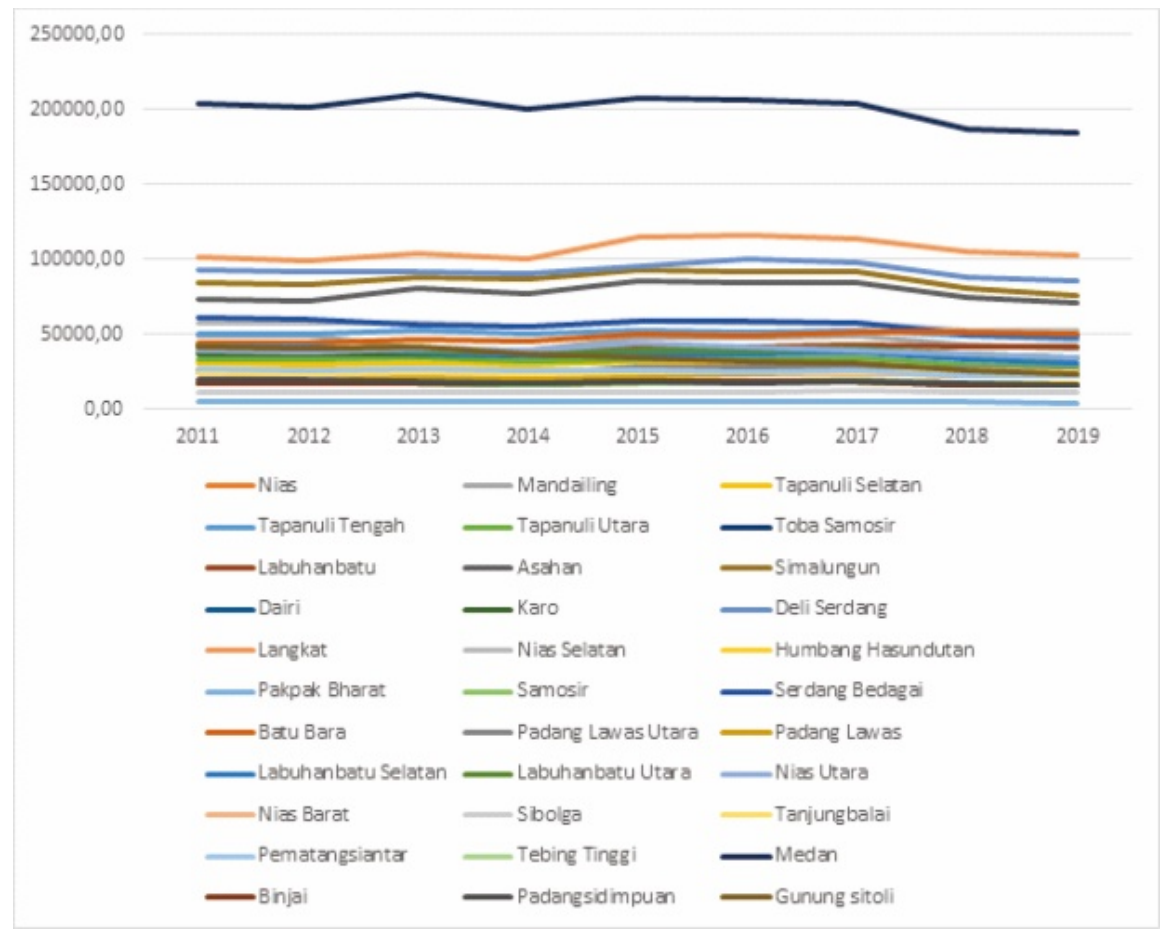

Gambar 1. Grafik Jumlah Penduduk Miskin (orang) di Provinsi Sumatera Utara Tahun 2011-2019. 


\section{ANALISIS KORELASI SEKTOR PERTANIAN DENGAN KEMISKINAN \\ DI PROVINSI SUMATERA UTARA}

Siti Sabrina Salqaura

Gambar 1 merupakan grafik yang menggambarkan jumlah penduduk miskin yang ada di kabupaten dan kota Provinsi Sumatera Utara. Secara umum jumlah penduduk miskin cenderung konstan dan sedikit berkurang dari tahun ke tahun. Kota Medan merupakan kota dengan jumlah penduduk yang paling banyak yaitu pada tahun 2019 sebanyak 14.562.549 jiwa, sehingga dapat dimaklumi jika jumlah penduduk miskinnya juga paling banyak diantara kabupaten dan kota lain. Diawal tahun 2011 jumlah penduduk miskin sebesar 204.190 orang dan diakhir tahun 2019 berkurang menjadi 183.790 .

Kabupaten Pakpak Bharat merupakan kabupaten dengan jumlah penduduk paling sedikit yaitu sebanyak
48.935 jiwa sehingga jumlah penduduk miskinnya juga sesuai dengan jumlah penduduknya. Diluar dari adanya hubungan antara jumlah penduduk dengan jumlah penduduk miskin, persentase penduduk miskin dapat lebih menggambarkan penduduk miskin. Berbeda dengan gambar 1 menurut persentase penduduk miskin dengan jumlah penduduk Kabupaten Nias Utara merupakan kabupaten dengan jumlah penduduk miskin paling banyak diantara Kabupaten dan Kota di Sumatera Utara yaitu sebesaar 55,55\%, kemudian Kota Gunungsitoli dan Kabupaten Nias Barat. Kabupaten yang paling rendah persentase jumlah penduduk miskinnya adalah Deli Serdang yaitu sebesar 11,87 persen pada tahun 2019.

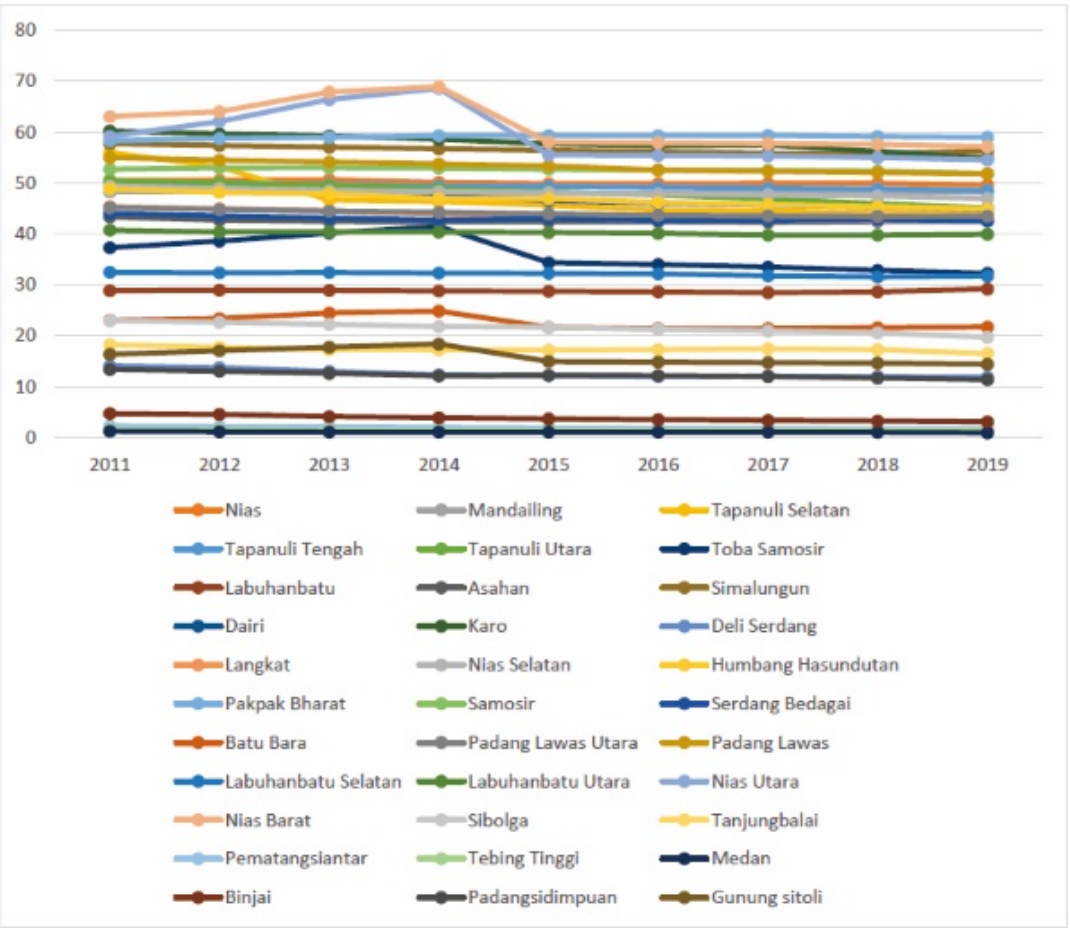

Gambar 2. Persentase Sektor Pertanian Menurut Kabupaten dan Kota di Provinsi Sumatera Utara. 
Gambar 2 merupakan grafik persentase sektor pertanian yaitu pembagian sektor pertanian dengan PDRB total Provinsi Sumatera Utara. Secara umum dapat kita lihat bahwa terjadi penurunan persentase PDRB sektor pertanian terutama untuk Nias Utara dan Nias Barat, penurunan persentase ini dapat disebabkan oleh peningkatan persentase pada sektor ekonomi lainnya. Nias Barat dan Nias Utara merupakan persentase sektor pertanian tertinggi di Provinsi Sumatera Utara. Pertanian cenderung pada daerah perdesaan hal ini juga dapat dilihat pada grafik tersebut bahwa daerah perkotaan seperti Kota Medan merupakan kota yang sektor ekonomi utamanya bukanlah sektor pertanian. Namun terdapat beberapa daerah kabupaten juga yang persentase PDRB sektor pertaniannya juga kecil. Persentase yang kecil bukan berarti sektor pertaniannya tidak luas ataupun tidak berkembang, namun persentase yang kecil menunjukkan bahwa terdapat sektor ekonomi lainnya yang persentase kontribusinya terhadap PDRB kabupaten atau kota tersebut lebih besar dari sektor pertanian.

Tabel 2. Analisis Korelasi

\begin{tabular}{lcc}
\hline & $\begin{array}{c}\text { Correlation } \\
\text { Probability }\end{array}$ \\
\hline Cases & Jumlah Penduduk Miskin & Sektor Pertanian \\
\hline Jumlah Penduduk Miskin & 1,000000 & \\
& ---- & 1,000000 \\
\hline Sektor Pertanian & 297 & --- \\
& 0,449111 & 297 \\
\hline
\end{tabular}

Sumber : Hasil Analisis Korelasi Ordinary

Tabel 2 merupakan hasil analisis korelasi dengan menggunakan software eviews ordinary. Hasilnya menunjukkan terdapat hubungan positif dengan signfifikansi sebesar 0,000 sebesar 0,4499 , artinya terdapat korelasi yang cukup kuat karena berada di kisaran 0,4 0,599. Angka 297 merupakan sampel atau jumlah data pada penelitian ini. Hubungan yang positif antara sektor pertanian dengan jumlah penduduk miskin artinya kedua variabel tersebut memiliki hubungan yang sejalan. Jika sektor pertanian mengalami peningkatan maka kemiskinan juga akan meningkat, juga sektor pertanian menurun maka kemiskinan juga akan menurun.

Hasil analisis ini tidak sesuai dengan penelitian Sihombing \& Bangun (2019) yang menunjukkan terdapat korelasi yang kuat namun arah negative antara kemiskinan dengan sektor pertanian, juga dengan Jingdong et. al. (2016) bahwa pertumbuhan pertanian 


\section{ANALISIS KORELASI SEKTOR PERTANIAN DENGAN KEMISKINAN \\ DI PROVINSI SUMATERA UTARA}

Siti Sabrina Salqaura

memberikan dampak yang penting terhadap penurunan kemiskinan dan Cervantes-Godoy \& Dewbre (2010) bahwa selain pertumbuhan ekonomi penting untuk mengurangi kemiskinan namun pertumbuhan pendapatan sektor pertanian juga penting untuk mengurangi kemiskinan. Namun beberapa penelitian menunjukkan bahwa terdapat ketidaksignifikanan antara sektor pertanian dengan kemiskinan seperti pada penelitian Niara \& Zulfa (2019) serta Mustika (2018) yaitu PDB sektor pertanian tidak berpengaruh signifikan terhadap kemiskinan di Indonesia dengan menggunakan data tahun 1993-2014.

Hubungan yang positif antara kemiskinan dengan sektor pertanian dapat kita lihat pada pembahasan gambar 1 dan gambar 2, bahwa persentase jumlah penduduk miskin di Nias Utara dan Nias Barat merupakan yang paling besar dan dilihat dari persentase kontribusi sektor pertanian terhadap PDRB kabupaten tersebut merupakan yang terbesar. Hasil penelitian ini juga sesuai dengan data jumlah penduduk miskin yaitu Kabupaten Asahan merupakan sentra petani perkebunan petani rakyat namun juga merupakan jumlah penduduk miskin kelima terbanyak. Perbaikan di sektor pertanian merupakan hal yang penting untuk mengentaskan kemiskinan di perdesaan mengingat mata pencaharian utama untuk penduduk perdesaan adalah dengan bertani.. Menurut Satriawan \& Oktavianty (2012) kemiskinan pada petani dapat disebabkan oleh banyak hal diantaranya kemampuan investasi petani yang rendah, ketergantungan petani, ketergantungan dana dan belum terpenuhinya kebutuhan pokok rumah tangga petani. Manajemen petani, pengelolaan petani dan edukasi ke petani dibutuhkan oleh petani.

\section{KESIMPULAN}

Analisis korelasi menunjukkan terdapat hubungan positif antara sektor pertanian dan kemiskinan yang artinya ketika terjadi peningkatan sektor pertanian dalam hal ini PDRB maka kemiskinan juga akan meningkat. Perlunya perhatian terhadap sektor pertanian, terutama sektor pertanian. Saran peneliti perlu dilakukan penelitian lebih lanjut tentang yang mempengaruhi kemiskinan dengan metode yang lain.

\section{DAFTAR PUSTAKA}

Anindita, A. 2017. Dampak Pertumbuhan Ekonomi, Jumlah Pengangguran terhadap Tingkat Kemiskinan di Kabupaten Sidoarjo. In Seminar Nasiional; FEB Unikama " Peningkatan Ketahanan Pangan Ekonomi Nasional dalam Rangka Menghadapi persaingan Global (pp. 130-137)".

Badan Pusat Statistik. 2020. Provinsi Sumatera Utara Dalam Angka. BPS-Statistics of Sumatera Utara Province. 
Cervantes-Godoy, D. \& J. Dewbre. (2010). Economic Importance of Agriculture for Poverty Reduction.OECD Food, Agriculture and Fisheries Working Papers, No. 23, OECD Publishing.

Eviews. 2020. eviews.com/help/helpintro .html\#page/content/groupsCovariance_Analysis.html. Diakses oleh Siti Sabrina Salqaura.

Mustika, C. (2018). Dampak Output PDB Sektor Pertanian terhdap Masalah Pembangunan Ekonomi di Indonesia (Kemiskinan dan Pengangguran). Jurnal Paradigma Ekonomika, 1960 (1), 22-28.

Niara, Ayu \& A. Zulfa. (2019). Pengaruh Kontribusi Sektor Pertanian dan Industri Terhadap Kemiskinan di Kabupaten Aceh Utara. Jurnal Ekonomi Regional Unimal. 2 (1): April 2019.

Pratama, Y. C. 2014. Analisis FaktorFaktor yang Mempengaruhi Kemiskinan di Indonesia. Jurnal Bisnis dan Manajemen Vol 3. No. 2 Agustus 2014.

Purnami, N. M. S. \& I. A. N. Saskara. 2016. Analisis Pengaruh Pendidikan dan Kontribusi Sektor
Pertanian Terhadap Pertumbuhan Ekonomi serta Jumlah Penduduk Miskin. E-Jurnal EP Unud, 5 (11) :1188-1218.

Rehman, A, Jingdong L., Khatoon R., Iqbal M. S. \& Hussain I. 2016. Effect of Agricultural Growth on Poverty Reduction, its Importance and Suggestions. Transylvanian Review. 24(5), Special Issue, 2016. Satriawan, B. \& Oktavianty, H. 2012. Menggunakan Model Tindakan Kolektif Kelembagaan Pertanian. Jurnal Ekonomi Pembangunan. 13 (1). 96-112.

Sihombing, A. O. \& Bangun, R. H. 2019. Analisis Korelasi Sektor Pertanian Terhadap Tingkat Kemiskinan di Provinsi Sumatera Utara. Agrica (Jurnal Agribisnis Sumatera Utara). 12(1): April 2019.

Zuhdiyaty, N. \& D. Kaluge. 2017. Analisis Faktor-Faktor yang Mempengaruhi Kemiskinan di Indonesia Selama Lima Tahun Terakhir (Studi Kasus Pada 33 Provinsi). JIBEKA. 11(2): $27-31$. 